Jurnal The Messenger, Vol. 13, No. 3 (2021), pp. 256-270

P-ISSN: 2086-1559, E-ISSN: 2527-2810

DOI: $10.26623 /$ themessenger.v13i3.2047

\title{
Information Disruption in Online Journalism in the Era of the Industrial Revolution 5.0
}

\author{
Anna Puji Lestari' ${ }^{1}$ Fitri $^{2}$ \\ ${ }^{1}$ ORCID ID: 0000-0001-9699-6751, Universitas Islam Negeri Walisongo Semarang, Jl. \\ Walisongo No. 3-5, Semarang, Central Java 50185, Indonesia \\ ${ }^{2}$ ORCID ID: 0000-0002-1316-8692, Universitas Islam Negeri Walisongo Semarang, J1. \\ Walisongo No. 3-5, Semarang, Central Java 50185, Indonesia \\ *Corresponding author, e-mail: fitrifdk@walisongo.ac.id
}

\begin{abstract}
This study examines the barriers to online journalism in the 5.0 industry era in facing market competition. This research was conducted on suaramerdeka.com as a large newspaper company in Central Java that can still survive in the midst of global competition in the mass media competition. Critical perspective with Fairclough's Critical Discourse Analysis design used in this study. The novelty of this research is specifically to answer the challenges of online journalism in the era of the industrial revolution 5.0 in terms of human resources. The findings of this study are related to the routine of news production in the suaramerdeka.com media, the speed of news updates, the accuracy and balance of the news. The human resources of news seekers and editing teams are not yet fully prepared to face the challenges of the new era. The results of this study shows that 1) the news production dependent on HR factor, company factor and managing editor; 2) the news delivery planning dependent on the market need, the news content of the printed Suara Merdeka aims at fulfilling the needs of the people of Central Java, suaramerdeka.com seeks to meet the needs of the people of Central Java around the world.

Keywords: Industrial Revolution 5.0, Online Journalism, Critical Perspective, Information Disruption, suaramerdeka.com.
\end{abstract}

\section{Introduction}

Suara Merdeka is one of the major media in Central Java, up to now it still survives in the midst of sophistication in communication technology. The main product offered to the public is newspapers, and along with the times this media presents news or information using digital platforms. The presence of the internet influences a press company to adapt. Suaramerdeka.com is here to become today's media, in other words, this is news that can be accessed on digital platforms. Suaramerdeka.com is a business division of Suara Merdeka Network which is engaged in online news. Founded on September 14, 1996 by Tommy Hetami, the online media is located at www.suaramerdeka.com. Initially, this website only contained printed editions of news taken from the print media of Suara Merdeka Daily. On 11 February 2000, Suara Merdeka added the news with the News Actual edition and other channels. This News Actual is intended so that suaramerdeka.com always provides the latest information (Novitasari, 2012).

The existence of suaramerdeka.com is an interesting thing to study, considering that this media has remained strong from time to time. Suaramerdeka.com is an integrated media that not only displays messages in written form, but is more varied. The change from conventional media to digital media takes time and process. This happens because print and digital media have different characteristics. Likewise with the market share of print and digital media. Suaramerdeka.com has a place in public, considering that it is more practical to access information, media readers turn to digital media. It can be said

Article History: Received March 02, 2020; Revised March 04, 2021; Accepted December 15, 2021; Published December 31, 2021 
that technological sophistication is unavoidable in the media industry, where technology is used to support journalism work. The movement of the era is now starting to be seen, it is no longer based on the 4.0 era but is now introduced to the 5.0 era.

There are several studies related to this study, including: first, the latest research on the industrial revolution 5.0 by Özdemir \& Hekim (2018) entitled "Birth of Industry 5.0: Making Sense of Big Data with Artificial Intelligence, The Internet of Things and NextGeneration Technology Policy." The results of the study show that industrial revolution 5.0 is poised to leverage extreme automation and Big Data with security, innovative technology policies and responsible implementation science, made possible by 3D symmetry in innovation ecosystem design. When compared with the previous research, the research in this paper is relatively new. The novelty of this research is to specifically address the challenges of online journalism in the era of the industrial revolution 5.0 in terms of human resources.

Second, Supadiyanto's research (Supadiyanto, 2020) entitled: “(Opportunities) Death of Newspaper Industry in Digital Age and Covid-19 Pandemic." In this case, researcher explain newspaper industry is entering a state of emergency in Indonesia. The results of this research, the growth in the number of internet users has been extraordinary in the last 20 years. Signs of the newspaper era are over, strengthened by many newspaper companies turning to online media. The number of readers fell, the number of advertisers plummeted, number of copies narrowed, and the cost of producing newspapers became increasingly expensive to cause the closure of various newspaper companies. Rescue by attracting young readers and doing various innovations. Digital media can be a solution to the crisis.

Third, "Print Media Newsroom Integration in Central Java (Study of Suara Merdeka and Jawa Pos Radar Semarang News towards Journalism Convergence)" by Permatasari (2020). Conlclude that the media convergence of Suara Merdeka and Jawa Pos Radar Semarang (JPRS) is carried out in four important areas, namely Project Scope, Newsroom Management, Practicals Journalism, and Organizational Work. Based on the analysis conducted, this study concludes that Suara Merdeka and JPRS have not shown a clear Media Convergence Model. Ownership even though media and production infrastructure have implemented a full integration model but in journalistic practice and newsroom management still mostly implements cross-media and isolation coordination platforms.

Fourth, "Artificial intelligence and sports journalism: Is it a sweeping change?" by Yair Galily (Galily, 2018). The profession of journalism has come under scrutiny in the domain of sociology research, the journalism. Throughout this paper, the author have tried to inquire whether the recent introduction of automatically produced content is merely another evolutionary stage in the field of sport journalism, or whether it has triggered an insurrection, that will dissolve human journalists from the profession. Ultimately shaping a new order, one where artificial intelligence replaces human journalists. This paper argued that the question should not be a dichotomous one of whether (unavoidable) technological determinism is merely right or wrong, but a set of questions of degree, scope, and context.

Fifth, "From the Print Press to Online Press: Contrains and Liberties of the Journalistic Discourse”, (Gavriliu (Mărgărit), 2012). This paper explained digital practice was born of new behaviours. This work aims to answer the questions mentioned by using the appearance of two Romanian national newspapers and their online counterpart's written versions for a week. In terms of journalistic discourse, there are certain gaps. This 
study aims to highlight the changes in discourse and the transformations of journalistic language practices between the two types of media. As far as we know, his type of comparative study for the Romanian press has not yet been performed.

The explanation above can be concluded that the press industry has developed with the advent of digitization. The number of online media is now more than conventional media such as newspapers, magazines, radio and television. Chairman of the Indonesian Press Council, Yosep Adi Prasetyo noted that there were 47.000 media in Indonesia in 2018 (Ashari, 2019). In this case, the press media is starting to adapt to the industrial revolution 4.0 that utilizes the Internet (IoT), data, and artificial intelligence, as well as artificial intelligence. Now, the press is required to prepare for the entry of the 5.0 industrial revolution era. This industrial concept was created by Japan on January 21, 2019. The rapid development of technology, including the presence of robots with intelligence which is considered to be able to replace the role of humans, then lies behind the birth of Industry 5.0 which can be interpreted as a concept of a human-centered society (human-centered) and technology-based.

The industrial revolution 5.0 emphasizes the importance of human intelligence creating and utilizing artificial intelligence, not the other way around. In the world of journalism, the system of sending and broadcasting news via the internet is not a new thing. Moreover, almost all conventional newspapers have web pages and YouTube channels. In an era in which independent journalism is flourishing in social media and appears to be changing the world of journalism, it is important to understand and identify how the culture of online journalism differs from the features of traditional journalism (Laor \& Galily, 2020). However, all of that was not enough. In the era of the industrial revolution 4.0, journalists are required to master all kinds of technologies that make the news reporting and writing process efficient. A journalist is required to be able to act as a news reporter, photo reporter, and also a video reporter at the same time.

However, in the era of industrial revolution 5.0, the position of communication technology as the key to development must be overturned and returned to the state that humans are actually the key to intelligence and technology is only a tool controlled by humans to achieve goals, not the other way around. Therefore, this study examines the obstacles for journalists to face the industrial revolution 5.0 and the gatekeeping process of mass media which still contains information disruption.

Furthermore, to accurately explain the disruption of information in the era of industrial revolution 5.0, the historical situatedness is explained regarding the development of online journalism and capitalism in Indonesia. Here are the seven most popular online news sites in Indonesia from the Alexa Traffic Rank in 2018. Alexa.com is a website that has tools to measure website popularity based on traffic and visitors. This data is obtained based on ranking by country which is calculated from the average daily visitors and page views from Indonesia in the last 1 month.

The first popular ranking is detik.com. Detik.com provides the latest \& most complete news from Indonesia \& around the world. Founded in 1998 and merged with Transmedia under CT Corp since August 2011. Unlike other popular news sites, detik.com is not from print media. The second popular ranking is kompas.com. In order to keep up with the development of the compass era, an online news site, namely kompas.com, was also created. Previously known as Kompas Cyber Media or Kompas Online. Founded in 1995, kompas.com was reborn in May 2008 by improving content and architecture. 
The third most popular is tribunnews.com, an Indonesian online news site and the regional newspaper division of Kompas. This news site provides a wide range of local, national and international news. Tribunnews also provides a forum for the public to participate in sharing information or conveying ideas and empirical experiences that are beneficial to the life of the nation through two Tribunnews rubrics, namely Tribuners and Citizen Reporters.

The fourth popular ranking is republica.co. Indonesian. This site is an online version of the print media called Republika. Republika itself is a national newspaper that was born from the Muslim community in Indonesia. Republika premiered on January 4, 1993. The fifth popular ranking is okezone.com. This website was officially launched on March 1, 2007. This online portal is owned by PT Media Nusantara Citra (MNC), a company that also manages several other media businesses such as television, print media, and radio networks.

The sixth popular ranking is tempo.co. Tempo.co was founded in 1996 by Yusril Djalinus, Bambang Bujono, S. Prinka, and Saiful B. Ridwan under the name Tempointeraktif. Previously, PT Tempo Inti Media, Tbk. The weekly magazine Tempo was born which was persecuted twice during the New Order era. Next, the seventh is betweennews.com. This site is owned by the Public Company, Antara National News Agency (or abbreviated Perum LKBN Antara). Perum LKBN Antara is a BUMN assigned by the Government to cover and disseminate fast, accurate and important information throughout Indonesia and internationally.

Given that a country's political system influences media industry policies, this section explains the historical location of the development and capitalization of the media industry in Indonesia. The development of mass media in Indonesia basically reflects the transition from state regulation to market regulation (Hidayat, 2003). This is where the operation of the media industry is no longer based on state intervention but rather on the form of market mechanisms and is determined by market forces (Sunarto, 2009).

The indicator is the rupiah earned from cake advertisements by print media companies. Based on data from Nielsen Consumer and Media View 2017, total newspaper advertising revenue is still at IDR 21 trillion. If the details of advertising revenue, the following categories, Hotels and Restaurants still advertise in print media with a share of 97 percent, then the Health and Medicine category and the Shop/Shop Specialist category each have a high share of advertising in print media with $95 \%$, followed by Category of Formal Education Institutions (89\%). Meanwhile, the share of advertisements in print media in the Multivitamin and Supplement Category is 18 percent, and the Communication Tools and Services category is still 12 percent.

The presentation of the data aims to show the existence of a mass media capitalization crisis which is very appropriate to be studied from the point of view of political economy. This study uses a political-economic approach in analyzing the policies produced by a mass media company. The political-economic approach of the mass media sees the media in their influence on the economy. One way to understand the monopoly of media capitalism is to look at the dominance of capitalism in the world of communication politically and ideologically (Mufid, 2009).

When compared with the types of newspapers circulating in the market in the 1990s and those that emerged in the 1970s, there are striking differences. During the New Order, political alliances were put forward, and also access to information has been heavily controlled by the authorities (Kurnia et al., 2021). Whereas in the reform era until now, 
the press has turned to business orientation and market sectors which are segmented based on the socio-economic conditions of the readers.

In the past (until the early 1970s), the press in Indonesia mainly functioned as a 'political media' linking editorial policies with segments of society with a particular political orientation, since the 1980 s most of the media directed their products to the general public by crossing social boundaries, culture, and politics to reach the widest and attract many advertisers (Hidayat, 1999).

The capitalization of the media is allegedly due to the large number of businessmen who have entered the press industry since the Soeharto regime's leadership. These entrepreneurs have absolutely no knowledge and experience of journalism, they only know how to make a profit through the press business. In the era of President Soeharto (second president of the Republic of Indonesia), the press was in the era of state regulation because the press was used as a tool to strengthen the ruling regime. The government has intervened a lot, among others, by limiting the number of daily newspaper pages to a maximum of 32 pages, limiting the number of advertisements in daily newspapers, or limiting the newspapers that may be circulated (Armando, 2016).

Tamin in H. Cangara (2009) said If there is a press that makes harsh criticisms of the government, it will be immediately closed and the publication permit revoked In fact, the New Order regime was characterized by the habit of labeling parties who were not liked or considered to threaten the status quo, for example negative nicknames such as PKI, extreme left, extreme right, anti-Pancasila, subversive, bonek (Mulyana, 2005)

Regarding state regulations in the New Order era, 1965 was the worst period in the history of the independent Indonesian press. In February and March of that year, 29 newspapers were banned because they supported the Communist Party. Then, 46 of the 163 newspapers were closed because they were suspected of being related to or sympathizing with the PKI. Furthermore, in 1974 and 1978 there were mass clashes by the New Order government.

People are not satisfied with the action. The New Order government responded to public discontent that led to demonstrations on January 15, 1974 by revoking the licenses that had been issued (IP) and printing permits (PP) for several newspapers, including Nusantara, DailyWE, Indonesia Raya, Abadi, The Jakarta Times, Weekly Happy, Indonesian Youth, Weekly Express News Magazine, Guidelines (from Jakarta), Suluh News (Surabaya), Indonesian Students (Bandung), and Indonesia Pos (Ujung Pandang). Only two were allowed to reissue after overhauling and reducing their staff (Hill, 2011).

During the 1980s, a number of publications were closed one by one by the government, such as the Ekuin Journal, Expo, Sinar Harapan, Suara Pembaruan, and Prioritas. Then, in the 1990s the Monitor tabloid was banned, editor-in-chief Arswendo Atmowiloto was arrested. The reason is, Monitor has a questionnaire of people's opinions that put the Prophet Muhammad at number 11 on the list of popular people. The first popular person was President Suharto, the 10th popular person was Arswendo Atmowiloto. A number of Islamic activists want the tabloid banned and the editor-inchief sent to prison.

In 1994, the New Order government through the Minister of Information revoked the licenses of Tempo, Detik, and the Editor. The media was judged to have made a mistake by the New Order government for issuing various criticisms about the president's family business, human rights violations, defects in government administration, and including various other sharp criticisms (Hill, 2011). 
The existence of the Minister of Information who held the authority for all press matters became a scourge for all press at that time. In addition, the authority is also in the hands of the Directorate General of Press and Graphic Development, which oversees press organizations to remain subservient to the government. The Ministry of Information also has a monopoly on the supply and distribution of various printing inks which are the basic ingredients of print media and regulates a series of production prerequisites (Hill, 2011). This control is really done to direct press information.

The New Order regime at that time implemented a system of control and censorship in the name of 'national unity' or 'development'. This regime often exercised strict control over all media to direct the information provided to the public in accordance with the wishes of the regime in power at that time. The New Order regime wanted all the news in the mass media to be about supporting the Suharto regime's policies.

In the period 1980-1990, a series of deregulations took place in the Indonesian economy which showed Indonesia's enthusiasm to further merge into the global market economy. Indonesia was then targeted by transnational investors. The government of President Soeharto then encouraged the growth of the consumptive middle and upper class society as a prerequisite for economic growth (Armando, 2016).

Business enthusiasm was responded to by the behavior of the domestic media. During this period, there was a strengthening of the commercialization process of the mass media, which was marked by the continued depoliticization of the press (the shift from the 'political press' to the 'business press'). In this case, the mass media, which initially prioritized political functions, gradually emerged as business fields that brought financial benefits to their owners (Armando, 2016).

The entry of media capitalization in Indonesia occurred since the mid-1980s, during the leadership of President Soeharto. At that time the kingdom of Media Indonesia Group/Surya Persindo emerged. This group provides an overview of someone who has no journalistic experience investing in the press industry. This press conglomerate is a big businessman in diversifying into regions with a clear investment strategy. One of the strategies undertaken by Acehnese entrepreneurs is to expand from the catering business to a publishing company by establishing PT Surya Persindo which produces Prioritas (Hill, 2011).

Actually, Surya Paloh's entry into the press industry is not the only one. There are a number of indigenous Indonesian businessmen who invest heavily in the press industry, for example Sutrisno Bachir from the Ika Muda business group. Then, a number of entrepreneurs flocked to the print media industry since the media boom of the 1980s. The Suharto family also entered the electronic (not printed) press industry by establishing RCTI, TPI, and SCTV. Then in 1989 there was a merger of the interests of the television media with prints made by members of the Suharto clan for profit motives. For example, Hardiyanti Rukmana published the Indonesian Women tabloid, she herself served as chairman and chairman of the publisher. This tabloid provides eight pages to load the TPI program. Automatically there is a relationship between the authorities and media entrepreneurs. For example, between Surya Paloh's Surya Persindo and Bambang Trihatmojo's Bimantara group (Hill, 2011).

The press in Indonesia today has indeed entered the industrial world. Advanced technology is used in the production process, both for printing and as editorial work aids, such as computers, and so on. The field of management and organization adapts to technological advances. Differentiation of tasks and roles in the organizational structure is carried out. The products produced collectively are organizational products, so press 
publishing becomes an industrial activity. If we follow the spirit of progress that wants to make our country an industrialized country, of course this must be supported. However, this industrialization seems to really follow the capitalist system. Discourse about the consequences of capitalism in the media can not be separated from the media industry that develops between the starting point of the interests of society and the state before finally being squeezed between the siege of capital and power (Mufid, 2009).

\section{Methods}

The type of research we use is the qualitative descriptive of critical perspective with Critical Discourse Analysis design. The study on discourse was also done at the meso level or Discourse Practice analysis. The analysis at this stage is the dimension related to the text/news production process. A news basically is produced through the production process of media texts, such as how the work patterns, the work charts and the routines in producing news (Fairclough, 2010). News is produced in specific ways, with routines and structured work patterns based on the reporters' reports in the field, or from news sources that will be written by editors and so on. For the distribution of text/news, it depends on the pattern and the type of text, and how the nature of the institutions inherent in the news.

Thus, the types and sources of primary data in this study were in-depth interviews with the Editor in Chief and Managing Editor as the controllers of the news production at suaramerdeka.com. While the types and the sources of the secondary data of this study were obtained from: (1) the observations of the worker interactions in daily situations at suaramerdeka.com for one week (February 26, 2018-March 4, 2018); (2) the written and visual documentation of the results of interactions among the actors at suaramerdeka.com; (3) the written and visual documentation related to the organizational system of suaramerdeka.com company. Then, data reduction will be conducted by using Spardley's data analysis technique. Spardley summarized the 'Gradual Advance Research Flow' which consists of five principles, namely: (1) the researchers are encouraged to use only one technique of collecting data; (2) identifying the main steps in the technique, for example the 12 main steps in an ethnographic interview from Spardley; (3) each main steps is executed sequentially; (4) practice and exercise must always be done; (5) providing problem solving as social responsibility, not just science for science anymore (Spardley, 1997).

\section{Results}

This session presents the research findings related to the news production routines at suaramerdeka.com, the speed of news update that precisely override the accuracy and the balance of the news, as well as the human resources of the news seekers which in fact have not been fully prepared for the industrial revolution 5.0. The results of this study refer to the concept of 'Gatekeeping on 5.0 Society adoption.' The term Gatekeeping is used as a metaphor to describe the selection process in the media work to broadcast news through the media 'door' to the digital platform of suaramerdeka.com. The idea of Gatekeeping theory is applied into decisions regarding the distribution and the marketing of the news products. In a broader sense, this idea refers to the power to give or to limit access to different voices in the society and often becomes a place of conflict (McQuail, 2011). 
The News Production Routine at suaramerdeka.com

The actual news editor at suaramerdeka.com acts as the editor. The editor consists of 8 people, each of whom works according to rheir work shift, not based on a trial or specialization. The actual news editor working per shif is five hours. Within 5 hours they are required to edit and upload 15 to 20 news to suaramerdeka.com site. While for the video editor at suaramerdeka.com, there are two people, each of whom is required to edit the videos sent by online journalists. Each video editors is required to edit and upload 3 to 5 videos every day.

Suaramerdeka.com reporters are five people. Each of them is required to send at least three news along with photos (images) of the events covered every day to Suaramerdeka.com. In addition, suaramerdeka.com reporters are required to send videos to the video editor to fill the SMTV channel. The technical news search for reporters at suaramerdeka.com is as follows: the reporters receive assignments from the office to cover an event and the reporters also look for the latest events, after the reporters find the latest events, the reporters look for the informants to be interviewed. After conducting the interview process, the reporters must immediately write it as news from the field (maximum 30 minutes), then send it at that time to the office email to be edited by the editors on duty.

When covering a particular event, at the time they arrive at the location of coverage the reporters initially records the moving images for the video so as not to miss the moment. Then, the reporters take photos and interview the informants. This is conducted so that the journalists can fulfill submitting video, photo, and news obligations. The news and photos must be sent as soon as possible, but it is different with the video recordings obtained. The large video recording files require the reporters to come to the office to hand them directly to the video editor on duty, usually in the afternoon.

As a comparison, the number of news sent by suaramerdeka.com and printed Suara Merdeka journalists is the same, namely minimally 3 news items per day along with photos. The difference is that the printed Suara Merdeka reporters do not need to record the video of the event they cover, suaramerdeka.com reporters are required to record the video of the event they cover to fill the SMTV channel. Suaramerdeka.com reporters are required to send the news they cover as soon as possible via email. One reporter whom the researchers met said that the informants whom they interview could be one, then directly written into the news. If they wanted the opinion of other informants, it can be used for the next news. Meanwhile the printed Suara Merdeka journalists are not required to send news as soon as possible so they can find other informants as a counterweight to be interviewed. Usually the printed Suara Merdeka reporters just wrote all the results of the coverage that they got in the afternoon. Suaramerdeka.com also has channel that has teenagers themes that has one special editor. The editor coordinates two journalists who specifically cover youth-themed news.

News Delivery Planning at suaramerdeka.com

I Nengah Segara Seni as Managing Editor explained that the existence of suaramerdeka.com is the strengthening of the printed Suara Merdeka. Setiawan Hendra Kelana as the Chief Editor also stated the same thing. The Chief Editor explained that suaramerdeka.com is a printed media-based online media as the following statement: "So we are rather unique than the others. It means that we cannot escape from the printed newspaper itself, in the sense that we have to work together until later because online is leading then the printed newspaper won't be OK, or even the sales will decline and so on," said the chief editor. 
The managing editor explained that the big concept of suaramerdeka.com was to make Central Java becomes national by making more news content about Central Java (more than 60 percent) than non-Central Java news content. "Local (Central Java) news is more than 60 percent. We multiply the news on Central Java, because we have agreed that Central Java information is for Central Java people in Central Java and outside Central Java accessing suaramerdeka.com. Maybe now I haven't been able to fulfill that one hundred percent," he added.

Furthermore, the Managing Editor explained that it was impossible to compete with national online media because it would definitely lose, "Because of this, it must be known that the national news must be detik.com, vivanews, Kompas, they are the king of media in Indonesia," said the managing editor.

Regarding the news content at suaramerdeka.com, the Managing Editor explained that the policies taken were very depend on the market needs. If the news content of the printed Suara Merdeka aims at fulfilling the needs of the people of Central Java, suaramerdeka.com is different. Suaramerdeka.com seeks to meet the needs of the people of Central Java around the world, "... because the access is not just Central Java, Miss," said the managing editor. This, the managing editor continued, makes the approach to readers of printed Suara Merdeka and cyber is different, "So when our approach to readers is different, the editorial policy must be different. Our policy in addressing the news is also different," explained the managing editor.

Furthermore, the managing editor explained that the news content of suaramerdeka.com adopted a number of news from printed Suara Merdeka, "It could be one hundred percent (taking news from journalists of printed Suara Merdeka) because we are a group." In addition, suaramerdeka.com also has its own reporter, total 5 people. Each cyber reporters is required to deposit news 3 to 4 news every day, plus cyber reporters are also required to deposit video images on the news they cover as material to be uploaded to the SMTV channel.

In cyber journalism, the term channel is the same as the rubric in the printed newspaper. The managing editor explained that the concept of printed media only issued once a day so that cyber took advantage of the time space to broadcast the news as soon as possible.

The managing editor also explained that the existence of E-paper channels which published digital versions of printed newspapers did not reduce the sales of printed newspapers because it was intended for overseas readers, "For overseas readers it is not a problem", he said. Furthermore, the Editor in Chief of suaramerdeka.com also explained the same thing as the managing editor that the news broadcasted on suaramerdeka.com was mostly news from the reporters of Suara Merdeka printed media.

Regarding the assignment of printed journalists, Editor-in-Chief explained that the printed reporters were assigned by the editors at pronted Suara Merdeka. The explanation is as follows: "... because there is online media that must be managed as well, besides sending the news to the editorial of the newspaper, they also previously sent them to online media. I also have several reporters but they only exist in Semarang. So to search for the news is not all directly from me (command). Because in Semarang I have five reporters, each of whom already has their respective main task areas. There are those in the provincial government, some in Central Java DPD and politics, then there are those in the Semarang City Government and the DPRD in Semarang City, there are those that cover the economy, then crime, and sports." 
While regarding the selection of news to be broadcasred, the editor explained that he as the editor chose the news from the printed journalist to be adapted to the style of the online news language that must be more concise and compact. Whereas the news from cyber reporters is prioritized to be displayed on suaramerdeka.com site. Each printed and cyber reporter sends the news via e-mail to the email address of suaramerdeka.com office so that it can be accessed by editors to be edited immediately and then displayed on suaramerdeka.com site.

In this regard, the editor in chief explained that the average mindset of printed journalists is still writing for printed media so it must be changed into online version before it is broadcasted to suaramerdeka.com. The editor in chief explained that this was understandable because not all printed journalists could write in an online style because of limited time and running news that had to be fast.

In addition, the Editor in Chief explained that at suaramerdeka.com the term desk is not known as a term often present in printed media. At suaramerdeka.com, they only know about coverage division. Regarding the news search process by reporters, Editorin-Chief explained that journalists had their own initiative to search for the news. However, he also stated that there were times he assigned reporters to cover certain events. Online media is closely related to the quantity of news, the editor in chief targets in 24 hours minimally airing 200 news on suaramerdeka.com site with 8 editors who handle editing and broadcasting. The policy is done because if the news broadcasted is less than 200, it cannot be detected by the Google search engine. In addition, the Editor in Chief also plans (not yet realized) to increase the quantity of news broadcasts to 250 up to 300 news each day with the addition of the editor.

Furthermore, the Editor in Chief explained that in order to be read by Google, the writing of the title and the news terrace (lead) must also be made different from other online media news narratives that have been broadcasted first. This is done because the editor in chief hopes that suaramerdeka.com is in the first rank of search engines and in the future he wants suaramerdeka.com to become a reference newspaper in Central Java for the readers who want to know the latest news.

Regarding the quantity of news, the editor stated that on average the news from cyber reporters would be published because in 24 hours a lot of news were needed to be published. When examined, of course this system has a weakness when pursuing quantity without considering the quality. Because, a lot of news on suaramerdeka.com, especially the news of rape has not touched the news balance (cover both side) so that it cannot be said to have fulfilled verification. Based on the Guidelines for cyber media coverage, it is stated that in principle each news must be through verification. On the news that can harm other parties (news of rape), requires verification on the same news to fulfill the principle of accuracy and balance.

The Managing Editor explained that suaramerdeka.com sought to follow the market's wishes. The implication, he explained, was that the policies presented at suaramerdeka.com were market demands, as the following explaination,

"Suaramerdeka.com is a translation of the demands of our market. So if in the newspaper the term rubrication is not our real desire, it is the demand of our readers, want this, want that, that's why we open it in the form of a channel on .com." Market oriented or market orientation weakness is that if applied in mass media companies, it will result in obscuring the objectivity of the news. 
Disruption Information Pattern Adoption Process of suaramerdeka.com.

Suaramerdeka.com journalists cover the news based on their own initiatives (looking for an update event on the field) and based on the assignments given by the Editor in Chief, Editor on duty and the editor. The editor receives the news submissions obtained by suaramerdeka.com and printed Suara Merdeka journalists, then edits them and there was a process of enriching the news by the editor. The news from suaramerdeka.com journalists are prioritized airing. Suaramerdeka.com reporters are required to send news of at least 3 every day. As for printed journalists, the editor in chief explained that he could not give order to printed journalists. However, the printed reporters had the awareness of sending news to suaramerdeka.com both the regional and national news. Furthermore, the news aired on the site of suaramerdeka.com. The readers of suaramerdeka.com target the Central Java community throughout the world.

Next, the Editor in Chief and the Managing Editor monitor the news that have been aired, if there is news that is felt to be 'improper,' then an evaluation process is conducted and addressed to the editor. News informants, Central Java community culture, advertisers, and market orientation set by the CEO of Suara Merdeka group helped shape the editorial policy of suaramerdeka.com.

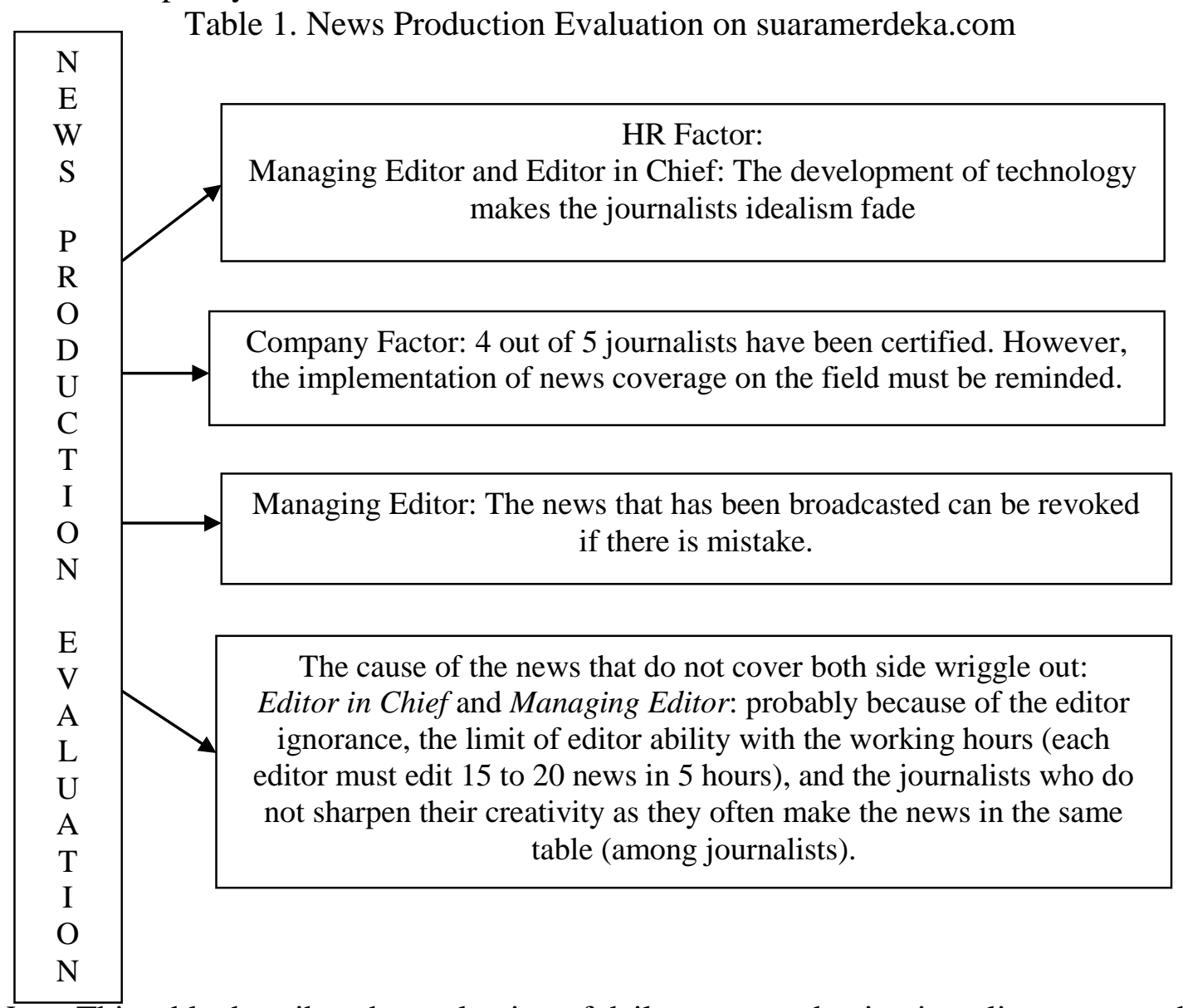

Note: This table describes the evaluation of daily news production in online mass media company (suaramerdeka.com)

\section{Discussion}

Disruption communication on online journalism era in industrial revolution 5.0 due to capitalization media. Capitalization and interconnected media industries then form into 
several categories. There are six categories or typologies of identifiable printed mass media, all of which appear to overlap each other.

The first category, is a series of large-scale empires which are driven by a number of established newspapers (which initially formed political alliances), especially Kompas and Suara Pembaruan. Now the two newspapers focus on newspaper production as profitable commodity rather than as mouthpiece of political movements from certain religious groups. Because of the middle and upper class readers, the newspapers are seen as qualified newspapers. The second category is professional business ventures that are apolitically driven by markets such as Jawa Pos and Media Indonesia. A new set of 'business' and 'economy' newspapers that emerged after 1985 such as Bisnis Indonesia and Neraca fall into this category.

The third category is the 'struggling press' which managed to survive like Merdeka. The fourth category is pro-government or pro-military newspapers such as Suara Karya, Angkatan Bersenjata, Berita Yudha, and Pelita. The fifth category is small-scale and circulation newspapers which automatically have small capital. They are regional newspapers that do not belong to the empire press. They try hard to stay on the market. The sixth category is sensational entertainment press like Pos Kota with lower class market share (Hill, 2011).

Suara Merdeka is in the second category press. Suara Merdeka is one of the major newspapers in the New Order era which at the beginning of its publication reached circulation of up to 170.700 copies (Hill, 2011). When the reform movement succeeded in overthrowing the New Order government, even SIUPP was no longer needed. This happened during the administration of President BJ Habibie. Furthermore, during the next administration era, with $\mathrm{KH}$ Abdurrachman Wahid as the president, not only was the SIUPP closed, the Ministry of Information was dissolved, and the Ministry of Social Affairs was removed from the composition of the cabinet (Wardhana, 2013).

The dissolution of the Ministry of Information and the Ministry of Social Affairs in Gus Dur's cabinet is indeed a monumental step taken by Gus Dur in connection with media freedom, or democratization in general (Wardhana, 2013). However, the freedom of the press offered by Gus Dur also seemed to have caused him bitter experiences. President Abdurrahman Wahid, who supported press freedom, when he was president he complained about the press which twisted his words a lot (Cangara, 2009). The many words of President Abdurrahman Wahid twisted by the press could be the proof that the media performed its functions not based on the logic of truth, but the economic logic. Although the freedom of the press provided by the government was so extensive due to the reform, however it had not been able to give birth to the aspiring civil society. The Press Council acknowledged that there was no good understanding on the freedom and independence of the press (Cangara, 2009).

Another example, based on the confession of a journalist in a newspaper in Semarang who did not want to be named said that the intervention of the media from the internal editorial causes the issuance of an information becoming not objective (Pratono, 2014). Politics of newsroom is also influenced by the fact that the media is actually not a sterile space from various interests (Adhiarso et al., 2018). The reality of the media is not always the same and congruent with public reality, because the news can be constructed by various interests, both from outside the media and within the media itself (Machmud, 2016). In line with this, according to Bantz, there are five things that encourage high atmosphere of contestation in newsroom, namely the tendency of journalists to always be suspicious and alert to external sources, the conflict between professional norms and 
business and entertainment norms, news competition among any same media, and the notion that news content always considers that conflict is important (Ishadi, 2014).

From the explanation above, it can be seen that at this time mass media perform their production more based on economic logic. Economic codes enter and increasingly get an important role. At this point, the practices of media business will be colored by the concentration and commercialization of the media, and simultaneously the media is always prone to violations of media ethics. Commercialization is detrimental to society because it cannot guarantee the freedom of the press and its integrity in realizing the truth. In fact, the commercialization of the media is able to threaten press autonomy especially in a political system that is inconsistent and colluding with the market (Cho, 2006).

Another possibility, free understanding of state control will also open up the dominance of commercial logic entirely to the practice of mass media. When the media consolidates with the ruling party or the dominant group, the result is not journalistic discipline. Instead, the collaboration between power and money will actually endanger the development of healthy journalism practices (Lee, 2001). The practice of journalism is increasingly widespread with technological developments. As technology develops, the printed media readers also use the Internet in their daily life which causes a high frequency of internet usage among the printed media readers. News platforms, or journalistic knowledge platforms, support computational journalism through integrated content and software components that support all stages of news production (Berven et al., 2020).

Nielsen Media Research data stated that the frequency reached $86 \%$, which is above the average of $61 \%$. As many as $65 \%$ of printed media readers access the internet via Smartphone and spend almost 3 hours of time with the Internet every day. Thus, the development of printed mass media must be synergy with the existence of the internet to support the distribution of information to the public. Journalism is challenged by digitalisation and social media, resulting in lower subscription numbers and reduced advertising income. Information and communication techniques (ICT) offer new opportunities (Berven et al., 2020). Also, from the perspective of human interest journalism, which is guided by commercial logic and oriented to readers as consumers, the media is seen as having the capacity to sell consumers to advertising organizations (Lica, 2013)

Discussing suaramerdeka.com from the description above, there are several things that need to be underlined for further study. Technological sophistication does not only have a positive impact on supporting reporting in journalistic work, such as the speed of news access, the amount of information presented or generating financial benefits. On the other hand, the impact of this technology can erode the potential of editors and journalists in carrying out their journalistic duties. We can find this in news that does not practice the element of cover both sides or balance. It is questionable why this could happen, the case could be due to internal and external factors. In terms of human resources managers because of ignorance, and working hours affect productivity. While external factors, digital media with its fast-paced characteristics demand timeliness.

Weaknesses that arise from technological sophistication in media work, media practitioners should pay more attention. Media convergence demands human resources to learn and work harder. This will be directly proportional to the work produced. The quality of the work will be seen if human resources are also prepared to face the industrial revolution, and vice versa. Human resources here are not only journalists as news makers, but also editors and editors or all parties involved in journalistic practices in the media. 


\section{Conclusion}

The practice of journalism is growing along with the sophistication of technology. The shift from conventional media to converged media with digital platforms is something that cannot be avoided by the press. It is no longer a lifestyle but the demands and needs for the fulfillment of information. Artificial intelligence in the era of industrial revolution 5.0 has an impact on the media, especially suaramerdeka.com which is the major media in Central Java, adapting and innovating according to the times, so that it can be accepted by the public. In practice, technology has a positive impact, related to news that is presented faster, more news. But on the other hand, with existing technology, the quality of news should be reviewed regarding accuracy and objectivity. In addition, in terms of human resources, readiness to face the industrial revolution needs to be well prepared, because it takes time and a process to become a reliable human resource, in addition to journalistic skills that need to be honed, mastery of technology needs to be improved. The urgent prospects for further research are how they relate to integrated journalism based on multiplatform, not only discuss the characteristics of the media and journalists, but also the challenges of era 5.0 viewed from communication, social, even economic point of view.

\section{Conflict of Interest}

We certify that there is no conflict of interest with any financial, personal, or other relationships with other people or organization related to the material discussed in the manuscript.

\section{Acknowledgements}

Researchers would like thank to the Editor in Chief and Managing Editor of suaramerdeka.com who are willing to be interviewed in this study, and also thank to authors of various references that researcher quoted.

\section{References}

Adhiarso, D. S., Utari, P., \& Hastjarjo, S. (2018). The Influence of News Construction and Netizen Response to the Hoax News in Online Media. Jurnal The Messenger, 10(2), 162-173. https://doi.org/http://dx.doi.org/10.26623/themessenger.v10i2.782

Armando, A. (2016). Televisi Indonesia di Bawah Kapitalisme Global. PT Kompas Media Nusantara.

Ashari, M. (2019). Jurnalisme Digital: Dari Pengumpulan Informasi Sampai Penyebaran Pesan. Inter Komunika: Jurnal Komunikasi, 4(1).

Berven, A., Christensen, O. A., Moldeklev, S., Opdahl, A. L., \& Villanger, K. J. (2020). A knowledge-graph platform for newsrooms. Computers in Industry, 123, 103321. https://doi.org/10.1016/j.compind.2020.103321

Cangara, H. (2009). Komunikasi Politik: Konsep, Teori, dan Strategi. Rajawali Pers.

Cho, L.-F. (2006). News Crusaders Constructing Journalistic Professionalism within the Confines of State Control and Commercial Pressure. Media Asia, 33(3-4). https://doi.org/https://doi.org/10.1080/01296612.2006.11726824

Fairclough, N. (2010). Critical Discourse Analysis, The Critical Study of Language. Pearson Education.

Galily, Y. (2018). Artificial intelligence and sports journalism: Is it a sweeping change? Technology in Society, 54, 47-51. https://doi.org/10.1016/j.techsoc.2018.03.001 
Gavriliu (Mărgărit), D. (2012). From the Print Press to Online Press: Constraints and Liberties of the Journalistic Discourse. Procedia - Social and Behavioral Sciences, 63, 263-270. https://doi.org/10.1016/j.sbspro.2012.10.037

Hidayat, D. N. (2003). Fundamentalisme Pasar dan Konstruksi Sosial Industri Penyiaran: Kerangka Teori Mengamati Pertarungan di Sektor Penyiaran. In Konstruksi Sosial Industri Penyiaran (Plus Acuan tentang Penyiaran Publik \& Komunitas) (p. 5). Penerbit Departemen Ilmu Komunikasi FISIP UI.

Hill, D. T. (2011). Pers di Masa Orde Baru. Yayasan Pustaka Obor Indonesia.

Kurnia, S. S., Kuswarno, E., Maryani, E., \& Firmansyah. (2021). The characteristics of investigative news organizations in Indonesia between 2010-2012. Heliyon, 7(2), e06276. https://doi.org/10.1016/j.heliyon.2021.e06276

Ishadi, S. (2014). Media \& Kekuasaan: Televisi di Hari-hari Terakhir Presiden Soeharto. PT Kompas Media Nusantara.

Laor, T. \& Galily, Y. (2020). Offline vs Online: Attitude and behavior of journalists in social media era. Technology in Society, 61, 101239. https://doi.org/10.1016/j.techsoc.2020.101239

Lee, E. (2001). How the Mass Media Have Transformed World Politics. The Catholic University of America Press.

Lica, C. A. T. (2013). Genres and Publishing Techniques Specific to Promotional Journalism. Procedia - Social and Behavioral Sciences, 92(Lumen), 941-946. https://doi.org/10.1016/j.sbspro.2013.08.781

Machmud, A. (2016). Biografi Jurnalistik. Mimbar Media Utama.

McQuail, D. (2011). Teori Komunikasi Massa McQuail (6th ed.). Salemba Humanika.

Mufid, M. (2009). Etika dan Filsafat Komunikasi. Kencana.

Mulyana, D. (2005). Nuansa-nuansa Komunikasi: Meneropong Politik dan Budaya Komunikasi Masyarakat Kontemporer. PT Remaja Rosdakarya.

Novitasari, R. (2012). Peran Koran Suara Merdeka Dalam Mengapresiasikan Kondisi Politik di Kota Semarang Tahun 1982-1999. Journal of Indonesian History, 1(2).

Özdemir, V., \& Hekim, N. (2018). Birth of Industry 5.0: Making Sense of Big Data with Artificial Intelligence, "The Internet of Things" and Next-Generation Technology Policy. OMICS: A Journal of Integrative Biology, 22(1), 65-76. https://doi.org/doi:10.1089/omi.2017.0194

Permatasari, V. A. A. (2020). Integrasi Newsroom Media Cetak Jawa Tengah (Studi Pada Harian Suara Merdeka Dan Jawa Pos Radar Semarang Menuju Konvergensi Jurnalistik). Jurnal Komunikasi Dan Media, 1(1), 55. https://doi.org/doi:10.24167/jkm.v1i1.2849

Pratono, dkk. (2014). Menulis di Bawah tekanan. In AJI (Ed.), Dalam Potret Intervensi di Bilik Redaksi (p. 27). Aliansi Jurnalis Independen (AJI) Semarang.

Spardley, J. P. (1997). Metode Etnografi. PT Tiara Wacana.

Sunarto. (2009). Televisi, Kekerasan dan Perempuan (1st ed.). Penerbit Buku Kompas.

Supadiyanto, S. (2020). (Opportunities) Death of Newspaper Industry in Digital Age and Covid-19 Pandemic. Jurnal The Messenger, 12(2), 192. https://doi.org/10.26623/themessenger.v12i2.2244

Wardhana, V. S. (2013). Budaya Massa, Agama, dan Wanita. PT Gramedia. 